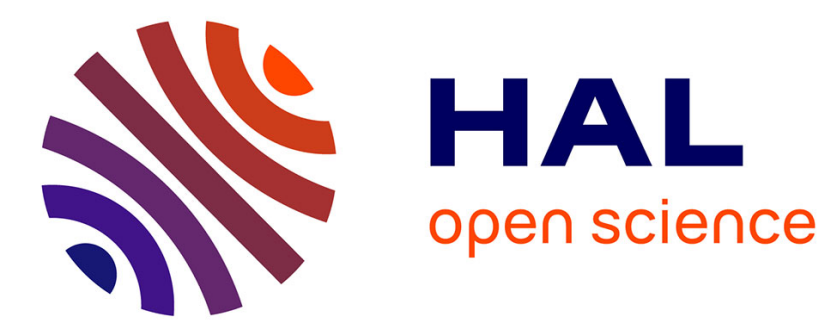

\title{
Exploring Sustainable HCI Research Dimensions Through the Inclusive Innovation Framework
}

\author{
Tobias Nyström, Moyen Mustaquim
}

\section{To cite this version:}

Tobias Nyström, Moyen Mustaquim. Exploring Sustainable HCI Research Dimensions Through the Inclusive Innovation Framework. 13th IFIP International Conference on Human Choice and Computers (HCC13), Sep 2018, Poznan, Poland. pp.151-165, 10.1007/978-3-319-99605-9_11 . hal-02001951

\section{HAL Id: hal-02001951 \\ https://hal.inria.fr/hal-02001951}

Submitted on 31 Jan 2019

HAL is a multi-disciplinary open access archive for the deposit and dissemination of scientific research documents, whether they are published or not. The documents may come from teaching and research institutions in France or abroad, or from public or private research centers.
L'archive ouverte pluridisciplinaire HAL, est destinée au dépôt et à la diffusion de documents scientifiques de niveau recherche, publiés ou non, émanant des établissements d'enseignement et de recherche français ou étrangers, des laboratoires publics ou privés. 


\title{
Exploring Sustainable HCI Research Dimensions through the Inclusive Innovation Framework
}

\author{
Tobias Nyström ${ }^{[0000-0002-4326-2882]}$ and Moyen \\ Mustaquim ${ }^{[0000-0003-0598-7257]}$ \\ Uppsala University, Sweden
}

\begin{abstract}
When frameworks and design principles for open innovation and open sustainability innovation (OSI) were established in earlier research, their foundations were originated from the expanded concepts of universal design (UD) from human-computer interaction (HCI) in a prescriptive form. This also was the basis of an inclusive innovation framework (IIF) aiming for a sustainable information system design. In this paper the IIF originating from the concept of combining UD and open innovation (OI) in promoting information technology enabling sustainability goals was analyzed together with OI and OSI frameworks. The role of OI in formulating the IIF was thereby strengthened, which in parallel helped recognizing the extended conceptions of sustainable HCI (SHCI) and its future research path through the use of IIF.
\end{abstract}

Keywords: Inclusive Innovation Framework, Open Innovation, Open Sustainability Innovation, Sustainability, Sustainable HCI, Universal Design.

\section{Introduction}

The importance of sustainability has been acknowledged in academia, and different research fields contribute to the pursuit of a sustainable future. Research in computer science, information systems, and HCI directed towards sustainability has predominantly been focused on environmental sustainability with the goal of reducing the use of resources, e.g. saving electricity and water, and increasing recycling or lowering emissions of carbon dioxide [1]. These goals are esteemed ones, but a more potent solution could be attained by using a holistic perspective when moving society towards sustainability. To be able to do so, the system design should correspond to different sustainability goals. Keeping these in mind, IIF was proposed by Mustaquim and Nyström [2] for increasing sustainability goal achievement through the design of an IT system.

However, when considering a design process for system development it is vital to realize how the design process should be shaped and organized for the success of that process [3]. Many theoretical frameworks in the form of instructions have increased the problem of structuring a design process instead of appropriately guiding and helping the designers choose which process to follow and thereby gain a better design result. Consequently, this paper brings the IIF one step 
further forward in the attempt and exploration towards explaining the concept of SHCI. In this paper we have analyzed IIF using the reason-centric perspective of design, while two other preceding frameworks that work in parallel as a subset of IIF were analyzed using an action-centric perspective of design. The analysis showed that OI could successfully support IIF. The reason-centric properties of the IIF could successfully satisfy some of the new SHCI research trends, which confirmed that an IIF is apt for contributing in the system development on which SHCI is focused. To do so, six identified suggestions for SHCI research by Silberman et al. [4] were mapped with the reason-centric properties of IIF.

The paper is divided into six sections. The background section introduces the theoretical foundations on which the research of this paper was formulated. Section 2 presents the analysis of IIF, OI framework, and the OSI framework with the Function-Behavior-Structure (FBS) and the Sensemaking-Coevolution-Implementation (SCI) frameworks. Findings from the analysis are then compared to the context of SHCI research parameters, which are also presented in section 3. In section 4 the IIF is explored in depth based on the findings from the comparisons within the context of SHCI. Finally, discussion and future work possibilities are given in section 5 , followed by a conclusion in section 6 .

\section{Background}

\subsection{The Inclusive Innovation Framework}

The IIF (Figure 1) was proposed to enhance the system development process by using four design principles taken from the UD concept that works to build the "inclusive innovation design space." By using the IIF system, designers will

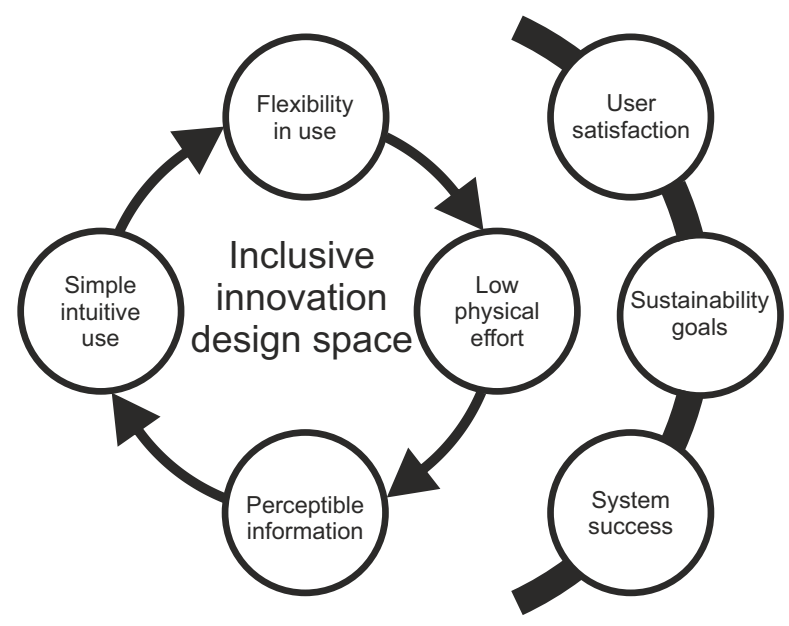

Fig. 1. IIF for sustainability (from [2]) 
have a higher chance of reaching user satisfaction; the set sustainability goals will follow and finally system success can be achieved. The four design principles to follow in design are:

- Simple intuitive use gained when the information from the system is easily perceptible, and if the user can employ the system without much effort.

- Perceptible information will, by the system design, guarantee that information presented through the system be accurate, easily perceptible, and need little physical effort.

- Low physical effort denotes that the system design incorporates flexibility and accordingly needs less physical effort during use.

- Flexible in use signifies the system design allowing flexibility and being used intuitively.

Through the system supporting actions the probability to achieve set sustainability goals increases. Hence, the user satisfaction parameter is crucial and should be manifested in the system's design strategy. To summarize the framework: by promoting the system designer's desired sustainability actions and/or goals, the system success phase should be reached if the system is easy to understand, remember, and learn, in addition to being simple and spontaneous. IIF is a holistic way of designing systems that tackle our dire situation concerning sustainability and increasing the possibility of reaching sustainability - a possible game changer.

\subsection{Open Innovation and Open Sustainability Innovation}

OI as a concept was introduced by Henry Chesbrough, but it is debated whether or not it is something genuinely new or simply a repackage of existing theories and practices in innovation strategies $[5,6]$. The different approaches and the lack of clear demarcations and definitions of innovation concepts like user innovation, OI, and crowdsourcing is apparent [2]. We see the strength and benefits of OI in its attempt to collect different innovation strategies, the emphasis on the importance to align innovation strategies with the overall business strategy, and its goal of bringing value and competitive advantage to a company. OI emphasizes the importance of external stakeholder involvement in the innovation process. This becomes crucial, especially when considering three identified important changes in "Research \& Development" [7]:

- First, a shortening of the technology cycle. The cycles, including scientific and technological developments and the product life cycle, have been slowly shortening and thus forcing companies to work harder on product development, e.g. the mobile phone industry, which the product life cycle of a specific phone model has decreased from around 1-2 years in the early 1990s to now be around 6 months. OI could improve the link between research and development. Hence, new product innovations could become faster if external stakeholders like suppliers and consumers could be involved. 
- Secondly, a technological explosion by around 90 percent of our present technical knowledge has been generated over the last 55 years. OI could improve the link with academic research through joint ventures, ideation, and new business incubator, etc.

- Thirdly, a globalization of technology and increased technological transfer in the form of strategic alliances and licensing has been noted by companies (especially in countries of the Pacific Rim) that have an ability to acquire and assimilate technology into new products, e.g. the creation in 2012 of a new company, "Japan Display Inc.," formed through the integration of Toshiba Mobile Display, Sony Mobile Display, and Hitachi Display. The company will carry out research and development in small and medium-sized displays [8]. OI implies that the business strategy incorporates the idea of an intellectual property (IP) market that makes it possible to sell, license, and acquire an IP to maximize the added value of both internal and external innovations. Hence designing a system that engages stakeholders by using OI strategies should increase the awareness and the possibility of reaching sustainability goals [9] and therefore the OI framework and OSI derives foundation from OI.

The OI framework consists of design principles that work in a logical sequence to achieve the overwhelming goal of increasing the stakeholder involvement that constitutes a prerequisite for OI and is therefore needed to accomplish a successful use of OI. The crucial components needed are: understanding of the importance of the business model, achieving extended user involvement, aiming for error reduction, and getting most users involved while eliminating restrictions [10]. OSI framework was constructed by using marketing theory that results in sustainable marketing and the basic buying decision that constitutes the purchase of a product. By using OI the end result could be a sustainability goal by a cyclic process that balances the customers' desired state and their requirements. Issues to be resolved are information presentation/communication, the gap between customers' desires and requirements, the convenience and support, and how to balance the added value compared to the cost [11].

\subsection{Sustainable HCI}

Academic sustainability research in HCI has burst in the recent years [1], [12], which also can be seen in the increase of sustainability as subjects and/or tracks in computer science, information systems, and HCI conferences. This trend has also been noticed in other research fields. The use of sustainability is unfortunately somewhat arbitrary and dependent on the author and context, since no definitive definition exists, albeit the UN's Sustainability Development Goals having been argued in recent SHCI workshops [13]. The sustainable definition used in this paper was based on the declaration of the world commission on environment and development (WCED) regarding sustainable development as meeting the needs of the present, but not to compromise for the future generation to meet its needs [14]. Most research in SHCI is limited towards only dealing 
with environmental sustainability [1], [15] and SHCI has previously been focused on reducing carbon dioxide emission, resource reduction by changing individuals' behavior towards consumption, and all these attempts through the design of systems [16]. Bates et al. [12] emphasized that broadening our understanding of how to redesign technology, systems, and society is of uttermost importance in a SHCI context. The essence of shaping the individual's behavior towards sustainability is critical and the design, thereby, plays an essential role in the transition to a sustainable society [17], although some argue a move beyond the individual to attain traction when considering sustainability [4], [18].

The different frameworks developed by Mustaquim and Nyström could be used as philosophical guidelines to follow in order to increase the chance of reaching a set sustainability goal. A broader consideration of sustainability is also imperative due to the complexity and multidimensionality of sustainability, e.g. the triple bottom line (TBL) [19] that considers three components: the natural environment, society, and economic performance. Another viewpoint is given by the quadruple bottom line (QBL) [20], which states that sustainability is linked to personal needs, environmental needs, and social needs in which economical concern is a means to satisfying these needs. There are further frameworks to choose from. Which of these we prefer is not as vital a point as understanding the complexity and interconnection of variables that constitute sustainability. We need to consider a holistic view of sustainability when we design systems [21]. SHCI should therefore not be limited to only environmental concern if we want to achieve a truly sustainable system. Another consideration is the predominant focus on human needs and thereby omitting to give value and voice to other animals and living things. The designer of systems must be cautious when designing, since its influential power could give an unintentional and unconscious result [17].

\section{Analysis, Comparison, and Findings}

The designer should contribute new knowledge by answering questions relevant to human problems, by the creation of innovative artifacts which must be built and then evaluated $[22,23,24]$. The foundation of the design science paradigm can be found in engineering and the sciences of the artificial [3]. For analyzing the IIF an engineering design process theory titled "FBS framework" was selected. A representation of IIF with the FBS framework is shown in Figure 2. The expected behavior of the structure is considered to yield "user satisfaction" and a predicted behavior of the structure is "system success." The expectations from the artifacts and their results are different sustainability goals, from which occasional transformation would occur with UD principles. Nonetheless, functional reformulations could occur between UD principles and sustainability goals while behavioral reformulation could occur between UD principles and user satisfaction in the form of transformation. User satisfaction and system success could be used for evaluation, e.g. in the form of a comparison or benchmarking of the designed system. Remy et al. [13] emphasized the need of SHCI to validate 


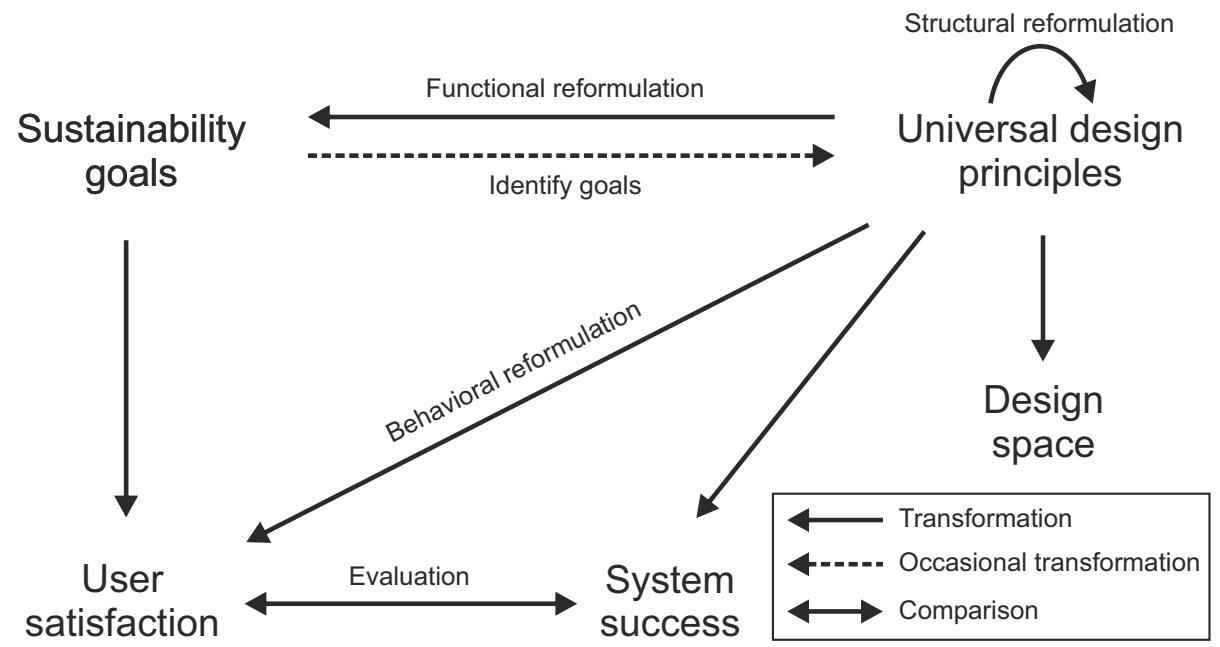

Fig. 2. A representation of IIF using the FBS framework (adapted from $[25,26]$ )

and showcase why a design solution works by thorough evaluations. Finally, the knowledge of UD principles could be transformed into the inclusive innovation design space.

In the FBS framework the purpose of the design is perceived as the successful transformation of certain functions into a design description to facilitate the described artifact as able to produce the addressed functionalities [26,27]. The rationale behind selecting the FBS framework is that it reflects a reason-centric perspective of the system design. In reason-centric perspective the cognitivist view of human action is described as a sequence of different sets of action with some preconceived end [26], [28] and a design could then be viewed as a plandriven problem solved by triggering any replanning due to unanticipated conditions [26]. In the IIF the end design should reflect the addressed functionalities in the framework and each function could furthermore be viewed as a different set of actions with a desired end goal. Replanning could be necessary to implement successfully each of the functions from which each function implementation could be viewed as a plan-driven problem-solving strategy.

Alternatively, the OI and OSI frameworks were analyzed using the SCI framework adapted from Ralph [29], which emphasized the action-centric perspective of system design, as opposed to the rational decision-making, i.e. reason-centric perspective[26]. Social constructivism theorizes that social interaction constitutes what knowledge creation is based on and an action-centric perspective of the design. Therefore, the SCI framework could be viewed as a consistent reflection of a conversation between the designers and situation [26], [29]. Both the OI and OSI frameworks from Mustaquim and Nyström [10,11] were based on the concept that improved design could be derived through interaction. Hence, it would be rational to use an action-centric perspective of design to analyze 


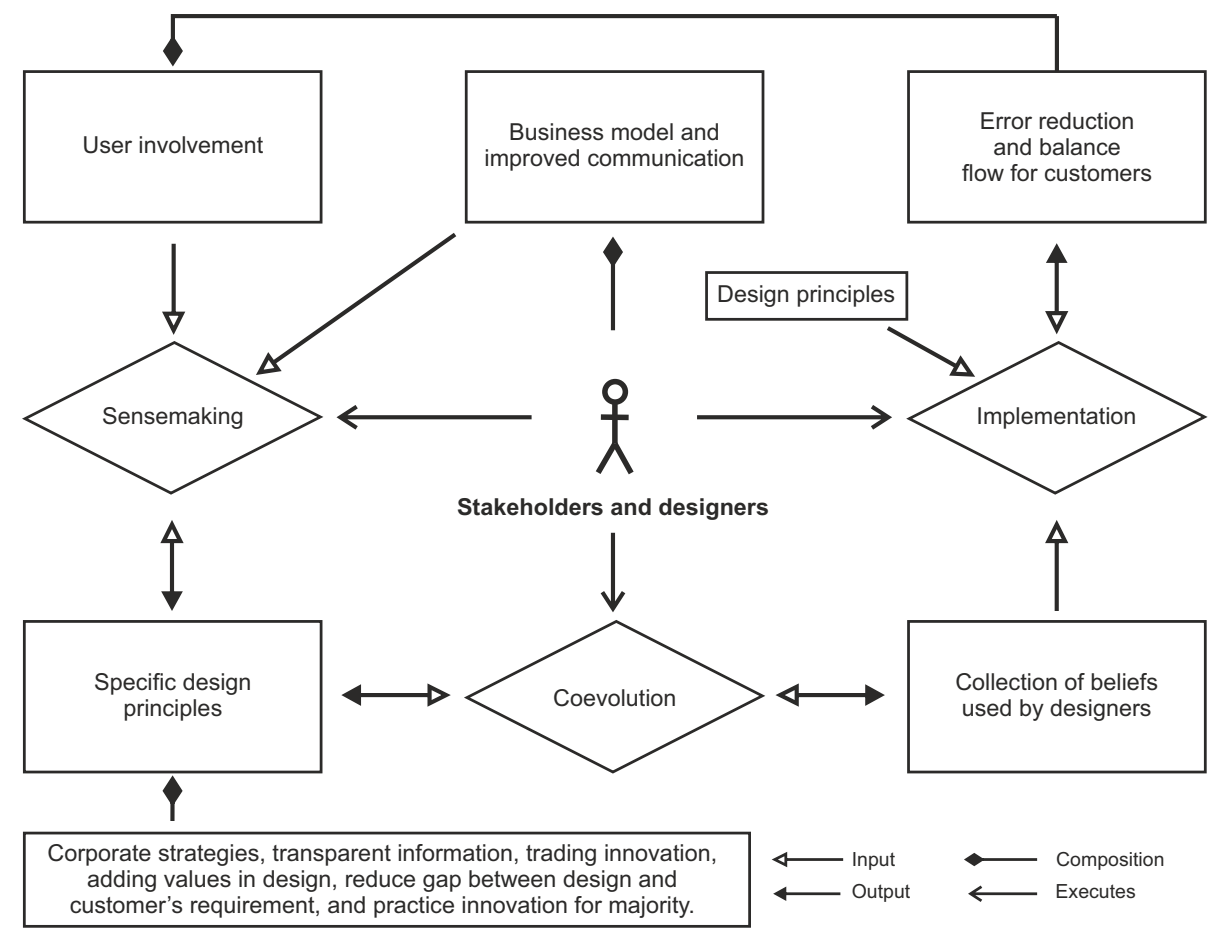

Fig. 3. A representation of OI and OSI frameworks using the SCI framework (adapted from [26])

the OI and OSI frameworks. A representation of the SCI framework within the context of OI and OSI is shown in Figure 3. The operations and concepts of the FBS and SCI frameworks were adapted from Ralph [26], and these two frameworks' corresponding meanings for the IIF (from [2]), OI framework (from [10]), and OSI framework (from [11]) were plotted and presented in Table 1 and 2. Figure 2 and 3 were based on the operations and concepts of these two tables.

A comparison between the reason- and action-centric perspectives of the three addressed frameworks, highlighted through the SHCI dimensions, were then generated and presented in Table 3. These dimensions of SHCI design issues were selected from the work of Silberman et al. [4]. The authors identified the selected six dimensions that address the next steps and efforts towards what SHCI research should aim at. Based on the factors listed in Table 3, conclusions were drawn. Thus SHCI, through the practice of IIF in system design, is explored and discussed in section 4 . 
Table 1. Operations of the FBS framework and its corresponding meanings for the IIF

\begin{tabular}{|c|c|c|c|}
\hline Operation & Inputs & Outputs & $\begin{array}{l}\text { Meaning in Inclusive } \\
\text { Innovation Framework }\end{array}$ \\
\hline Analysis & $\begin{array}{l}\text { Inclusive innovation } \\
\text { design space }\end{array}$ & $\begin{array}{l}\text { Sustainable } \\
\text { information } \\
\text { system }\end{array}$ & $\begin{array}{l}\text { The process of deriving the } \\
\text { sustainability goals, user } \\
\text { satisfaction, and system success }\end{array}$ \\
\hline $\begin{array}{l}\text { Catalog } \\
\text { Lookup }\end{array}$ & $\begin{array}{l}\text { User satisfaction, } \\
\text { system } \\
\text { success and } \\
\text { sustainability }\end{array}$ & $\begin{array}{l}\text { Inclusive } \\
\text { innovation } \\
\text { design space }\end{array}$ & $\begin{array}{l}\text { The appropriate design } \\
\text { structure to successfully } \\
\text { run the UD principles }\end{array}$ \\
\hline Evaluation & $\begin{array}{l}\text { User satisfaction } \\
\text { and sustainability }\end{array}$ & System success & $\begin{array}{l}\text { Comparison of user } \\
\text { satisfaction and sustainability } \\
\text { to determine if the design } \\
\text { structure will be able to } \\
\text { successfully use UD principles }\end{array}$ \\
\hline Formulation & $\begin{array}{l}\text { User satisfaction, } \\
\text { system success, and } \\
\text { sustainability }\end{array}$ & ability & $\begin{array}{l}\text { Derive sustainable behavior } \\
\text { from the set of UD } \\
\text { principles }\end{array}$ \\
\hline $\begin{array}{l}\text { Production of } \\
\text { Design } \\
\text { Documentation }\end{array}$ & $\begin{array}{l}\text { Inclusive } \\
\text { innovation design } \\
\text { space }\end{array}$ & $\begin{array}{l}\text { Inclusive innovation } \\
\text { design framework }\end{array}$ & $\begin{array}{l}\text { Transfer the selected design } \\
\text { structure to a design description } \\
\text { for system designers }\end{array}$ \\
\hline Synthesis & Sustainability & $\begin{array}{l}\text { Inclusive innovation } \\
\text { design space and } \\
\text { user satisfaction }\end{array}$ & $\begin{array}{l}\text { Sustainability is used as expected } \\
\text { behavior of the end system, based } \\
\text { on the knowledge of user } \\
\text { satisfaction with the system }\end{array}$ \\
\hline
\end{tabular}


Table 2. Different concepts of SCI framework and their meaning for OI and the OSI framework

\begin{tabular}{|c|c|c|}
\hline Concept & Meaning for OI Framework & $\begin{array}{l}\text { Meaning in OSI } \\
\text { Framework }\end{array}$ \\
\hline Constraints & $\begin{array}{l}\text { Removing any restriction from the } \\
\text { design objective of OI, by } \\
\text { practicing it for the majority }\end{array}$ & $\begin{array}{l}\text { Removing constraints to reduce the gap between } \\
\text { customer's requirement and desire }\end{array}$ \\
\hline Design agent & $\begin{array}{l}\text { Selection of a group of entities for } \\
\text { successful involvement of users } \\
\text { in a wide-ranging perspective }\end{array}$ & $\begin{array}{l}\text { Selection of a group of entities for making } \\
\text { information presentation for the customer a } \\
\text { less complicated task }\end{array}$ \\
\hline $\begin{array}{l}\text { Design object's } \\
\text { environment }\end{array}$ & $\begin{array}{l}\text { The totality of the wide range of user } \\
\text { involvement and contact that is } \\
\text { expanded through the academia }\end{array}$ & $\begin{array}{l}\text { Make information presentation about a product } \\
\text { for the customer an easy task }\end{array}$ \\
\hline $\begin{array}{l}\text { Design agent's } \\
\text { environment }\end{array}$ & $\begin{array}{l}\text { The totality of the whole business model } \\
\text { involved in OI practice }\end{array}$ & $\begin{array}{l}\text { The totality of the evaluation of product towards } \\
\text { differing alternatives and enhancing better } \\
\text { communication with customers }\end{array}$ \\
\hline Design objects & $\begin{array}{l}\text { The possibility of a reduced error objective, } \\
\text { through the help of OI }\end{array}$ & $\begin{array}{l}\text { Ensuring a balanced flow between different } \\
\text { variables of customer cost for successful } \\
\text { OSI practice }\end{array}$ \\
\hline Goals & $\begin{array}{l}\text { Realizing the corporate strategies properly } \\
\text { for understanding the effect of a wide range } \\
\text { of user involvement and thereby generating } \\
\text { the proper business model }\end{array}$ & $\begin{array}{l}\text { Provide transparent information to customers } \\
\text { for the positive impact on their } \\
\text { post-purchase behavior }\end{array}$ \\
\hline $\begin{array}{l}\text { Mental picture } \\
\text { of context }\end{array}$ & $\begin{array}{l}\text { Collection of design principles for system } \\
\text { designers in OI design process } \\
\text { and its designer's environment }\end{array}$ & $\begin{array}{l}\text { Collection of design principles for sustainable } \\
\text { innovation through OI }\end{array}$ \\
\hline $\begin{array}{l}\text { Mental picture } \\
\text { of design object }\end{array}$ & $\begin{array}{l}\text { Collection of beliefs used by the designers } \\
\text { to improve the design principles concerning } \\
\text { OI process }\end{array}$ & $\begin{array}{l}\text { Collection of beliefs used by the designers to } \\
\text { improve the design principles concerning OSI } \\
\text { process }\end{array}$ \\
\hline Primitives & $\begin{array}{l}\text { Set of design principles for a successful } \\
\text { user involvement initiation }\end{array}$ & $\begin{array}{l}\text { Appropriate business model for the successful } \\
\text { user involvement towards sustainable product } \\
\text { development through innovation }\end{array}$ \\
\hline Requirements & $\begin{array}{l}\text { The ability to trade innovation for increased } \\
\text { user involvement in the innovation process }\end{array}$ & $\begin{array}{l}\text { Ability to add values into the product design } \\
\text { for the convenience of the design process }\end{array}$ \\
\hline Sense-making & $\begin{array}{l}\text { Organizing the OI environment } \\
\text { for creating or refining a new business model }\end{array}$ & $\begin{array}{l}\text { OSI process planning through the } \\
\text { simplicity in the design process }\end{array}$ \\
\hline Coevolution & $\begin{array}{l}\text { Refining the OI process using } \\
\text { the mental picture of the extended } \\
\text { business model }\end{array}$ & $\begin{array}{l}\text { Provide error-free customer solutions for efficiency } \\
\text { during the OSI process and update the } \\
\text { mental picture of the designer for the innovation }\end{array}$ \\
\hline
\end{tabular}

Table 3. Comparison of two perspectives based on the SHCI dimensions

\begin{tabular}{|c|c|c|}
\hline SHCI Dimension & Reason-centric Perspective (IIF) & $\begin{array}{l}\text { Action-centric Perspective } \\
\text { (OI and OSI) }\end{array}$ \\
\hline $\begin{array}{l}\text { Specify and operationalize } \\
\text { goals }\end{array}$ & $\begin{array}{l}\text { The positivist approach using design principles } \\
\text { outside the traditional way of looking into HCI } \\
\text { for achieving sustainability through design }\end{array}$ & $\begin{array}{l}\text { Design work in sustainability discourse } \\
\text { outside HCI where the constructivist } \\
\text { approach leads towards innovation }\end{array}$ \\
\hline Longer timescale research & $\begin{array}{l}\text { Long-term design process by involving different } \\
\text { stakeholders triggering cumulative and iterative } \\
\text { design process for improved sustainability } \\
\text { achievement through design }\end{array}$ & $\begin{array}{l}\text { Long-term social and economic process } \\
\text { influencing OI and OSI method } \\
\text { for improved sustainability } \\
\text { address in practice }\end{array}$ \\
\hline $\begin{array}{l}\text { Building system for } \\
\text { everyday use }\end{array}$ & $\begin{array}{l}\text { Inclusive design process by making it possible to } \\
\text { fit in everyday product or system design and } \\
\text { evaluation, thereby building new knowledge } \\
\text { in the SHCI domain }\end{array}$ & $\begin{array}{l}\text { Direct influence of product design } \\
\text { through the OI and OSI }\end{array}$ \\
\hline $\begin{array}{l}\text { Draw from and support } \\
\text { work outside HCI }\end{array}$ & $\begin{array}{l}\text { Expanding the traditional usability concept from } \\
\text { HCI towards sustainability achievement by } \\
\text { user satisfaction and system success }\end{array}$ & $\begin{array}{l}\text { Gaining sustainability knowledge from } \\
\text { business research, using the OI and } \\
\text { OSI to produce new knowledge in SHCI }\end{array}$ \\
\hline $\begin{array}{l}\text { Diversifying sustainability } \\
\text { issues }\end{array}$ & $\begin{array}{l}\text { Bridging the gap between UD and } \\
\text { sustainability by diversifying traditional } \\
\text { sustainability issues under the shed of UD } \\
\text { and its principles }\end{array}$ & $\begin{array}{l}\text { Diversifying the SHCI scopes in new } \\
\text { research domains through the creative } \\
\text { practice of OI and OSI }\end{array}$ \\
\hline $\begin{array}{l}\text { Multi-scale, complex } \\
\text { sustainability problems }\end{array}$ & $\begin{array}{l}\text { Build new SHCI dimensions and actions } \\
\text { based on the traditional sustainability issues for } \\
\text { different artifact results and improved information } \\
\text { processing capabilities }\end{array}$ & $\begin{array}{l}\text { Escaping only the ecological sustainability } \\
\text { issues by focusing on larger systems with } \\
\text { different corporate strategies for practicing } \\
\text { OI and OSI }\end{array}$ \\
\hline
\end{tabular}




\section{Sustainable HCI and Inclusive Innovation Framework}

The six dimensions of SHCI for future research are discussed in this section in the context of basic notions of SHCI and their relations with the IIF. The IIF was constructed with four UD principles (as described in subsection 2.1) that would work in a circular process in the inclusive innovation design space (Figure 1.) This will also address three identified universal usability challenges: user diversity, technology variety, and gaps in user knowledge [30]. While the SHCI research field has mainly been concerned with designing technology to change human behavior on environmental impacts [12], [31] and designing technologies to reduce impact on the environment, an IIF for a system design process can contribute towards both of these dimensions of SHCI. By specifying and operationalizing certain goals through the design for sustainability, the dimensions of sustainability could be handled properly, since they exist independently. The IIF takes into account certain design goals and in that process look beyond the traditional way SHCI issues have previously been handled. The dimensions of sustainability are not independent themselves and therefore the definition of sustainability could vary depending on the situation and context. Hence, IIF in the design process could help in identifying the correct structured goal to define sustainability in the proper context of the problem.

The IIF could involve different stakeholders in the design process, since it is built within a design space of the OI. While much research has been conducted in the domain of SHCI in a little over a decade, it is possible to notice a trend of predominantly scientific publications with frameworks and design principles for small-scale/specific problems and design issues. IIF showed that the design process could be iterative and cumulative over time by involving multiple stakeholders; therefore suitable to handle large-scale design problems associated with sustainability issues. Persuasions could be initiated and tackled by the introduction of the IIF in the design process. Also, very few of the SHCI research results are inevitable today and may be seen as end products for user behavior change for sustainability. A design process that is inclusive and based on UD principles aiming for sustainable outcomes with proper user satisfaction and system success would undoubtedly tend to contribute in designing products and services for end users. The use of OI concept in the IIF design space influences this motivation towards truly designing products and services.

Several discussions have triggered the idea of using SHCI as a multi- and interdisciplinary research domain for collaborating with different research domains [1] (the roots of HCI are multidisciplinary [32]). Bringing external knowledge from other research domain and using it in the context of SHCI is interesting; the opposite is also necessary, i.e. to contribute other research domains from the SHCI perspective. Since sustainability is multidisciplinary in nature, the contribution from SHCI could be extensive in other research fields, which would extend HCI research possibilities together with contributions in other research domains. The traditional concept of usability engineering in HCI [32] could be expanded with IIF by looking into sustainability achievement through system success and user satisfaction, thus creating a completely new dimension of looking into sus- 
tainability through design). IIF is therefore highly promising and could probably contribute in the multidisciplinary research domain. Accordingly, SHCI research can see the sustainability problem as a more diversifying issue. The way SHCI looks into the sustainability problems (based upon the multidimensionality and many levels of analysis) have merely expanded its scope beyond academic publications. If the issues of sustainability are not diversified, then it might become trapped within its own loophole and make itself unsustainable. Diversification is therefore needed to perpetually define and redefine different sustainability problems. One such initiation of diversification could be started from a system design process to make the resulting design and the design process sustainable. IIF is designed to keep this in mind.

Creative practice of OI and OSI is expected within the design space of inclusive innovation, through which new knowledge about the sustainability problem could be identified and resolved. Finally, a complex view of sustainability would create the need and a demand to evolve design frameworks and design principles that are able to handle complex sustainability issues. Complex sustainability problems could be realized by practicing IIF during a design process. Considering large-scale system design and the involvement of different stakeholders in various social and political situations could lead the designers to realizing what sustainability is in that particular context. IIF could then contribute in achieving those sustainability goals. In conclusion, when discussing IIF and SHCI it could be said that the framework was revealed to be fitting for the purpose of SHCI research trends, as noticed from Table 3 . The research trend parameters were discussed in this section in detail to argue that IIF in a design process could be applied to create systems that can be used for changing user behavior in complex sustainability issues, in long-term design problems, and to create products and services for daily use. In other words, the IIF could reflect SHCI design issues and requirements in a design process.

\section{Discussions and Future Work}

One of the primary goals of system design science is to shape and organize design processes. However, considerable design science research in academia is more prescriptive and not exploratory [26], which has initiated the idea of exploring the earlier proposed IIF under the shade of SHCI. Empirically, it was shown earlier that action-centric process theory is more successful in describing the shape of system design than with reason-centric perspective [26] which favors supports of the OI and OSI frameworks, which are a subset of the IIF analyzed within the context of reason-centric perspective. Ralph [33] did evaluate FSB and SCI through a multi-methodological approach and found SCI to represent more accurately represent software development practice. It did, however, neither prove SCI nor falsify FSB for development of software. It is important to realize that the IIF, OI framework, and OSI framework are not meant to produce any technological artifacts; instead, a virtual artifact, which is how the differentiation between classical design science research and system design research should be 
perceived in this paper. One of such virtual artifacts was selected to be a sustainability issue from the IIF, analyzed within the context of SHCI. In favor of descriptive and explanatory validity of IIF for SHCI, the existing framework could be seen as a process model whereby usually the abstract description of a proposed process is usually presented [34]. The analysis and results of this paper could then be seen as a process theory for which the outcome of the IIF as a process model appeared in a generalized way, within the context of SHCI. On the other hand, the characteristic of the IIF in the context of SHCI also supports the genres and axes of SHCI identified by DiSalvo [1], when the authors raised and discussed issues like the requirement of application of the SHCI concept, thinking more than the traditional HCI concept; bigger, with large-scale and users' and group-design's problems.

Another aspect, called a "value-sensitive design approach," could be realized through the outcome of the results from this paper. Value-sensitive design is known to contribute to the foundation of different social issues in the HCI research [35]. Issues like sustainability could be an embodied value to incorporate in the design process for producing a good design outcome from the beginning and throughout a design process. Friedman et al. identified sustainability as one of the ethical principles to be used in value-sensitive design [36]. The IIF used four UD principles and the rationale was not philosophically grounded; rather, their selection was arbitrary. Therefore, by analyzing IIF using a reason-centric approach like FBS framework, it was grounded that a designer could be capable of controlling a design process, which is an information-processing metaphor supported by the reason-centric view, to satisfy a need like sustainability throughout the whole design process. However, as suggested by Ralph [26], a reason-centric perspective is a popular but questionable system design perspective. Actioncentric perspective is more consistent and pragmatic. The IIF should therefore demand empirical verification. Nevertheless, the FBS framework was used only to analyze IIF and not to specify the development process. How pragmatic it would be to analyze IIF using an action-centric framework was not the topic of interest in this paper and therefore has not been discussed. Possibilities and scopes of further research work will now be discussed, for which some constraints of this research will be highlighted too.

The next step of this research could be viewed from three different perspectives. Firstly, empirical validation of the IIF for justifying the SHCI dimensions is central to see that the opinions formulated from the SCI and FBS frameworks are valid in a system development setup. At the same time, it would be interesting to be pragmatic and see how the SHCI dimensions could be realized by putting the IIF into practice in system development. This could be achieved by analyzing how a design process followed by the IIF could shape an organization. A system could be analyzed in the different phases of its development life cycle to determine whether IIF is successful in terms of realizing the new dimensions of SHCI. Secondly, since the SCI and FBS frameworks were initiated by the need of a different software development perspective, a system development could be analyzed in terms of programming and coding of the software by following the 
IIF and observing how well the addressed SHCI issues would behave in such a setup. Finally, to analyze existing systems by taking them as different sample cases could be another choice to add new scopes into this research. Case study analysis may find new parameters to be added into the SCI and FBS frameworks' concept and operation, which would extend or find new dimensions for SHCI.

\section{Conclusions}

In this paper the previously established IIF for sustainable system development was analyzed together with the OI and OSI frameworks by using two existing reason- and action-centric frameworks (FBS and SCI). The IIF could create a design space which would be based on OI and OSI, and this was the rationale behind analyzing these OI and OSI frameworks together with IIF. The reasonand action-centric properties from IIF together with OI and OSI frameworks were then compared with six SHCI dimensions, which were identified in previous research to be the most important impending issues for SHCI research. The analysis showed that IIF aiming for sustainable system development could be successful in mapping itself towards describing the different dimensions of SHCI. The action-centric perspective for comparison strengthened the fact that OI and OSI could work as a support for the IIF for effective realization of different sustainability characteristics of a system, while at the same time reflecting SHCI research prospects in a new dimension.

\section{References}

1. DiSalvo, C., Sengers, P., Brynjarsdóttir, H.: Mapping the landscape of sustainable hci. In: Proceedings of the SIGCHI Conference on Human Factors in Computing Systems. pp. 1975-1984. CHI '10, ACM, New York (2010). https://doi.org/10.1145/1753326.1753625

2. Mustaquim, M., Nyström, T.: Designing information systems for sustainability the role of universal design and open innovation. In: Tremblay, M.C., VanderMeer, D., Rothenberger, M., Gupta, A., Yoon, V. (eds.) Advancing the Impact of Design Science: Moving from Theory to Practice. pp. 1-16. Springer International Publishing, Cham (2014). https://doi.org/10.1007/978-3-319-06701-8_1

3. Simon, H.A.: The sciences of the artificial. MIT press (1996)

4. Silberman, M.S., Nathan, L., Knowles, B., Bendor, R., Clear, A., Håkansson, M., Dillahunt, T., Mankoff, J.: Next steps for sustainable hci. interactions 21(5), 66-69 (Sep 2014). https://doi.org/10.1145/2651820

5. Trott, P., Hartmann, D.: Why 'open innovation' is old wine in new bottles. International Journal of Innovation Management 13(04), 715-736 (2009). https://doi.org/10.1142/S1363919609002509

6. Trott, P., Hartmann, D.: Open innovation: Old ideas in a fancy tuxedo remedy a false dichotomy. In: Open Innovation Research, Management and Practice, chap. 13, pp. 359-386. Imperial College Press (2013). https://doi.org/10.1142/9781783262816_0014 
7. Rothwell, R., Zegveld, W.: Reindustrialization and technology. Longman, London (1985)

8. Japan Display Inc.: Message from the president (2014), http://www.j-display . com/english/company/index.html, [Online; accessed 9-September-2014]

9. Mustaquim, M., Nyström, T.: Designing sustainable it system - from the perspective of universal design principles. In: Stephanidis, C., Antona, M. (eds.) Universal Access in Human-Computer Interaction. Design Methods, Tools, and Interaction Techniques for eInclusion. pp. 77-86. Springer, Berlin, Heidelberg (2013). https://doi.org/10.1007/978-3-642-39188-0_9

10. Mustaquim, M., Nyström, T.: Design principles of open innovation concept universal design viewpoint. In: Stephanidis, C., Antona, M. (eds.) Universal Access in Human-Computer Interaction. Design Methods, Tools, and Interaction Techniques for eInclusion. pp. 214-223. Springer, Berlin, Heidelberg (2013). https://doi.org/10.1007/978-3-642-39188-0_23

11. Mustaquim, M., Nyström, T.: Open sustainability innovation-a pragmatic standpoint of sustainable hci. In: Johansson, B., Andersson, B., Holmberg, N. (eds.) Perspectives in Business Informatics Research. pp. 101-112. Springer International Publishing, Cham (2014). https://doi.org/10.1007/978-3-319-11370-8_8

12. Bates, O., Thomas, V., Remy, C.: Doing good in hci: Can we broaden our agenda? interactions 24(5), 80-82 (Aug 2017). https://doi.org/10.1145/3121386

13. Remy, C., Bates, O., Thomas, V., Huang, E.M.: The limits of evaluating sustainability. In: Proceedings of the 2017 Workshop on Computing Within Limits. pp. 103-110. LIMITS '17, ACM, New York (2017). https://doi.org/10.1145/3080556.3080567

14. The World Commission on Environment and Development (WCED): Our common future. Oxford University Press (1987)

15. DiSalvo, C., Sengers, P., Brynjarsdóttir, H.: Navigating the terrain of sustainable hci. interactions 17(4), 22-25 (Jul 2010). https://doi.org/10.1145/1806491.1806497

16. Dourish, P.: Hci and environmental sustainability: The politics of design and the design of politics. In: Proceedings of the 8th ACM Conference on Designing Interactive Systems. pp. 1-10. DIS '10, ACM, New York (2010). https://doi.org/10.1145/1858171.1858173

17. Stegall, N.: Designing for sustainability: A philosophy for ecologically intentional design. Design Issues 22(2), 56-63 (2006). https://doi.org/10.1162/desi.2006.22.2.56

18. Knowles, B., Blair, L., Hazas, M., Walker, S.: Exploring sustainability research in computing: Where we are and where we go next. In: Proceedings of the $2013 \mathrm{ACM}$ International Joint Conference on Pervasive and Ubiquitous Computing. pp. 305-314. UbiComp '13, ACM, New York (2013). https://doi.org/10.1145/2493432.2493474

19. Elkington, J.: Towards the sustainable corporation: Win-win-win business strategies for sustainable development. California Management Review 36(2), 90-100 (1994). https://doi.org/10.2307/41165746

20. Walker, S.: The Spirit of Design: Objects, Environment and Meaning. Earthscan, London (2011)

21. Nyström, T., Mustaquim, M.: Sustainable information system design and the role of sustainable hci. In: Proceedings of the 18th International Academic MindTrek Conference: Media Business, Management, Content \& Services. pp. 66-73. AcademicMindTrek '14, ACM, New York (2014). https://doi.org/10.1145/2676467.2676486

22. Hevner, A., Chatterjee, S.: Design Science Research in Information Systems, pp. 9-22. Springer US, Boston (2010). https://doi.org/10.1007/978-1-4419-5653-8_2 
23. Hevner, A.R., March, S.T., Park, J., Ram, S.: Design science in information systems research. MIS quarterly 28(1), 75-105 (2004)

24. March, S.T., Smith, G.F.: Design and natural science research on information technology. Decision support systems 15(4), 251-266 (1995). https://doi.org/10.1016/0167-9236(94)00041-2

25. Kruchten, P.: Casting software design in the function-behaviorstructure framework. IEEE Software 22(2), 52-58 (March 2005). https://doi.org/10.1109/MS.2005.33

26. Ralph, P.: Comparing two software design process theories. In: Winter, R., Zhao, J.L., Aier, S. (eds.) Global Perspectives on Design Science Research. pp. 139-153. Springer, Berlin, Heidelberg (2010). https://doi.org/10.1007/978-3-642-13335-0_10

27. Gero, J.S.: Design prototypes: A knowledge representation schema for design. AI Mag. 11(4), 26-36 (1990). https://doi.org/10.1609/aimag.v11i4.854

28. Suchman, L.A.: Plans and situated actions: The problem of human-machine communication. Cambridge university press (1987)

29. Ralph, P.: The sensemaking-coevolution-implementation theory of software design. Science of Computer Programming 101, 21 - 41 (2015). https://doi.org/10.1016/j.scico.2014.11.007

30. Shneiderman, B.: Universal usability. Commun. ACM 43(5), 84-91 (May 2000). https://doi.org/10.1145/332833.332843

31. Blevis, E.: Sustainable interaction design: Invention \& disposal, renewal \& reuse. In: Proceedings of the SIGCHI Conference on Human Factors in Computing Systems. pp. 503-512. CHI '07, ACM, New York (2007). https://doi.org/10.1145/1240624.1240705

32. Hartson, H.R.: Humancomputer interaction: Interdisciplinary roots and trends. Journal of Systems and Software 43(2), 103 - 118 (1998). https://doi.org/10.1016/S0164-1212(98)10026-2

33. Ralph, P.: Software engineering process theory: A multi-method comparison of sensemakingcoevolutionimplementation theory and functionbehaviorstructure theory. Information and Software Technology 70, 232 - 250 (2016). https://doi.org/10.1016/j.infsof.2015.06.010

34. Curtis, B., Kellner, M.I., Over, J.: Process modeling. Commun. ACM 35(9), 75-90 (Sep 1992). https://doi.org/10.1145/130994.130998

35. Fuchs, C., Obrist, M.: Hci and society: Towards a typology of universal design principles. Int. J. Hum. Comput. Interaction 26, 638-656 (2010). https://doi.org/10.1080/10447311003781334

36. Friedman, B., Kahn, P.H., Borning, A., Huldtgren, A.: Value Sensitive Design and Information Systems, pp. 55-95. Springer Netherlands, Dordrecht (2013). https://doi.org/10.1007/978-94-007-7844-3_4 